AUTHOR TITLE

PUB DATE NOTE

PUB TYPE EDRS PRICE DESCRIPTORS
Wolverton, Mimi; Montez, Joni; Gmelch, Walter $H$. The Roles and Challenges of Deans. AsHE Annual Meeting Paper.

2000-11-00

29p.; Paper presented at the Annual Meeting of the Association for the study of Higher Education (ASHE) (25th, Sacramento, CA, November 16-19, 2000).

Reports - Research (143) - Speeches/Meeting Papers (150) MF01/PCO2 Plus Postage.

Administrator Attitudes; *Administrator Role; Conflict;

*Deans; Higher Education; Surveys

ABSTRACT

This study examined the relationships among the roles of college deans and conflict and ambiguity in deans' work. Challenges deans perceived as imminent in the future were also studied. The sample included 1,370 deans from 360 universities. They were asked about their roles, conflicts and ambiguities they faced, and possible challenges for the future. The responses show that deans are inevitably confronted with situations that require them to engage in roles that conflict with priorities that remain unfocused. They tended to identify challenges for the future as parallel to their current roles, suggesting that conflict and ambiguity will carry forward. The deanship as it exists today is enigmatic, and a major question centers on whether to fix the deans or the deanship. Professional development and training in time management may "fix the dean," but larger issues remain with colleges and universities that suggest that it may be time to fix the deanship through institutional responses that define priorities clearly. Shared leadership is a possible approach that may relieve some of the time pressures on academic deans. (Contains 5 tables and 41 references.) (SLD) 


\title{
THE ROLES AND CHALLENGES OF DEANS
}

By

Mimi Wolverton

Washington State University

Joni Montez

Washington State University

Walter H. Gmelch

PERMISSION TO REPRODUCE AND PISSEMINATE THIS MATERIAL HAS BEEN GRANTED BY

\author{
Iowa State University
}

U.S. DEPARTMENT OF EDUCATION
Offics of Educational Research and Improvement Olfice of Educational Research and Improvement CENTER (ERIC)

This document has been reproduced as received from the person or organization originating it.

a Minor changes have been made to

improve reproduction quality.

TO THE EDUCATIONAL RESOURCES INFORMATION CENTER (ERIC)

1

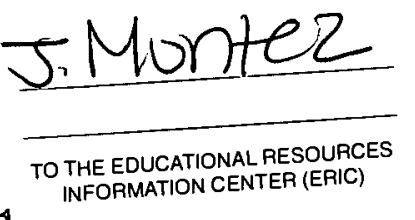

- Points of view or opinions stated in this
document do not necessarily represent official OERI position or policy.

Presented at the Annual Meeting of the Association for the Study of Higher Education

November 18, 2000

Sacramento, California

$m$

m

BEST COPY AVAILABLE

2 


\section{THE ROLES AND CHALLENGES OF DEANS}

\section{$\underline{\text { Introduction }}$}

By the very divergent nature of the position they hold, academic deans epitomize role conflict and/or role ambiguity. The forces of demands from their superiors (administration and boards of regents/trustees), their constituents (faculty and students), and their benefactors (taxpayers, legislators, and endowers)--all create a turbulent environment in which deans must operate. The success of the college depends upon the dean's performance; and, it is certain that the expectations of the faculty, administration, and benefactors will shape the dean's role. For instance, when a dean deals with the college's faculty, he/she may serve as a "buffer ... from the university's intrusion upon and usurpation of [the faculty's] professional autonomy" (Wolverton, Wolverton, \& Gmelch, 1999, p. 81). In an administrative context, the dean may be called upon to act as persuader, negotiator, or arbitrator. Paramount to the dean's survival, then, is the ability to maintain the equilibrium between his/her value systems and the situations that present themselves.

We can understand the problematic nature of the deanship by examining the roles performed in that position. As the face of modern universities change, the leadership inherent in them continues to require the "eminently rational solution to a massive problem of human and technological organization" (Kahn, Wolfe, Quinn, Snoek, \& Rosenthal, 1964, p. 4-5). In finding such a solution, universities are confronted with the need to make the parts and functions fit with the appropriate behavior of the organization's members. The conundrum, of course, is that this task is the greatest weakness of organizations and a high source of frustrations for its leaders.

This paper examines the relationship between deans' roles, conflict and ambiguity, and postulates that the kinds of challenges that deans anticipate in the future will not abate unless 
conflict and ambiguity are lessened. The paper discusses the implications of these issues and makes recommendations for easing the burden of the deanship from a personal, administrative, and positional perspective.

\section{Theoretical Framework}

\section{Role Theory}

Role theory provides the lens through which we examine the functions and behaviors, or roles, of academic deans today. The fundamental proposition of role theory is that behaviors within contexts (roles) are associated with persons who share a common identity (in positions) and who are aware of their roles (by expectations). Roles persist because of their consequences within a larger social system (functions) and, thus, persons must be taught (socialized into) these roles (Biddle, 1979). The integration of roles, positions, and expectations form the basis of this theory (Biddle, 1979; Kahn, et al., 1964). Establishing a clear relationship between these elements for the dean is requisite; without it, the role stresses of conflict and ambiguity emerge (Biddle, 1979; Gross, Mason \& McEachern, 1958; Kahn et al., 1964; Rizzo, House, \& Lirtzman, 1970; Wolverton, Wolverton \& Gmelch, 1999).

\section{$\underline{\text { Role Conflict }}$}

The pressures of the position, whether internal or external, will redirect the behavior of the dean (Kahn, et al., 1964). The notion of role conflict was described by Gross, Mason \& McEachern (1958) as "any situation in which the incumbent of a focal position perceives that he[/she] is confronted with incompatible expectations" (p. 248). When these expected behaviors are inconsistent, there is stress, dissatisfaction, and decreased effectiveness in performance (Biddle, 1979; Kahn, et al., 1964; Rizzo, et al., 1970). Intra-role conflict occurs when the expectations that others hold for a dean conflict. A disequilibrium results. Caught between the 
faculty and administration, between students and faculty, or between administration and public, a dean is expected to advocate for opposing sides of issues. This disequilibrium in a dean results from "the exposure of the [dean] to conflicting sets of legitimized role expectations such that complete fulfillment of both is realistically impossible" (Parsons, 1951, p. 280). Invariably, a dean in such a situation must choose to perform one task at the expense of another, adding to the stress of not being able to fully meet the expectations of his/her superiors or constituents.

Role Ambiguity

Another undesirable consequence of position-related pressures is role ambiguity. In order for a dean to perform adequately in his/her role, certain information is required: what the expectations (rights, duties and responsibilities) are, what activities must be done to meet the responsibilities of the position and how they are best performed, and what the potential consequences of role performance are (Kahn et al., 1964). Role ambiguity results when there is a lack of available information as to the scope and responsibilities of a dean's job (Biddle, 1979; Kahn, et al., 1964; Rizzo, et al., 1970). This unavailability results either because information is nonexistent or because it has been inadequately communicated (Kahn, et al., 1964, p. 23). Issues, such as change in organizational size, growth, technology, personnel, and culture, create a complex environment that oftentimes exceeds the "span of comprehension" (Rizzo, et al., 1970, p. 155) of a dean, thus muddying his/her vision of the job.

Reactions common to role ambiguity are increased tension and anxiety (Cohen, 1959; Kahn, et al., 1964; Wispe \& Thayer, 1957), hostility or a less favorable attitude toward a superior (Cohen, 1959; Kahn, et al., 1964), and decreased productivity (Kahn et al., 1964; Mandell, 1956). When a dean experiences these reactions, he/she may engage in adjustive and/or maladjustive coping behaviors, such as emotional management strategies, attempting to solve problems by 
avoiding the stress, or using defense mechanisms that distort reality (Gates, 2000; Kahn, et al., 1964; Rizzo, et al., 1970).

It is within the construct of role theory and, specifically, the consequences of role ambiguity and conflict, that we shaped the current study. In the remainder of this paper we examine deans' roles, the sources of conflict and ambiguity, and the resultant role challenges that deans perceive as imminent in the future.

\section{Deans' Roles in an Historical Context}

The academic deanship in American universities has evolved considerably since its meager beginnings in the 1800s. The chief function of the dean of Harvard's medical school in 1864 was, for example, to maintain "friendly and charitable intercourse with the students" (Dill, 1980). Reflecting considerable growth and expansion of responsibilities, a typical role description of academic deans in the 1960s focused on the ends and means of higher education in the institution, the teacher-scholars or scholar-teachers of the faculty, the academic program and its recipients, and academic budgets (Dibden, 1968). In 1979, Scott cited a more managerially oriented list of deans' concerns which included: (a) extraordinary circumstances (such as student protests), (b) budget items (salaries and operating expenses), (c) curriculum and program development and (d) faculty personnel issues (resignations, replacements for retirements, and tenure failures). In this evolution toward management, the addition of roles, such as strategic planning, fundraising, and developing and meeting institutional and external accountability measures, created more challenges to the deanship (Dill, 1980).

Today, the academic dean is involved with the college, the president, the faculty, and the curriculum in many ways different from other institutional members (Fagin, 1997). In the 1990s, the breadth of the dean's roles expanded to include representing the university within the 
community and recruiting diverse faculty and students from previously underrepresented groups (Wolverton, Gmelch, Wolverton, \& Sarros, 1999) as well as becoming political advocates for invoking the influence of college-outsiders, such as legislators and potential donors (Gardner, 1992). Evolving roles are constantly juggled as the constituents and their demands change. The ability to reconcile disparate demands, Fagin (1997) notes, is related to "the individual's clarity on what others see and value, recognition of the vital aspects of the role and responsibilities of dean in a particular university, and a honed balancing act" (p. 97).

\section{Methodology}

This study represents one aspect of the National Study of Academic Deans (NSAD), conducted in 1996 through the Center for Academic Leadership at Washington State University. ${ }^{1}$ Measures taken from the NSAD that are relevant to this study were the following:

1. Deans' Task Inventory (DTI; Sarros, Gmelch \& Tanewski, 1998; Gmelch \& Miskin, 1993)--this instrument sought to identify the importance of 32 typical tasks of the dean's role.

2. Role Conflict and Ambiguity Questionnaire (RCAQ; Rizzo, et al., 1970)--this measure comprised 14 items that assessed the level of perceived role conflict and role ambiguity in deans.

3. Open-ended question--this inquiry asked deans to (a) rank in order of importance the three biggest challenges that they faced in the 3-5 years to come, and (b) rate how effective each felt he/she would be at addressing each challenge.

The sample comprised deans from universities in one of the following three Carnegie classifications--Research, Masters, or Baccalaureate. From the initial group of colleges and universities, 60 public and 60 private institutions were randomly selected from each Carnegie category, resulting in a sample of 360 institutions. At each institution, the deans of the colleges (UCEA).

${ }^{1}$ Sponsored and funded in part by the University Council on Educational Administration 
of education, business, liberal arts, and nursing were asked to complete the survey. The response rate was $60 \%$.

To reduce the dimensionality of the data generated by the DTI and the RCAQ, principal components analysis with varimax rotation using the SPSS statistical package was employed. In each analysis, factors carrying eigenvalues greater than 1.0 were initially considered to be significant (Hair et al., 1992). In each factor analysis, the first factor to emerge accounts for the greatest amount of the variance in the inventory, and the variables loading more heavily on a specific factor are the most indicative of the underlying construct that the factor represents. The last factor to materialize in the analysis carries the least predictive reliability, as do the variables loading least heavily on a particular factor. Cronbach's alpha was calculated for variables loading most heavily on each factor within each analysis to determine the reliability of the inventory (Norusis, 1994). The factor analysis of the DTL is reported herein; the factor analysis of the $\mathrm{RCAQ}$, however, is not, because it served only as confirmation of previous research results (Rizzo et al., 1970). The mean scores of the individual RCAQ responses are presented to provide readers with a better picture of what constitutes role conflict and role ambiguity for deans than is revealed by the two composite factor scores.

In instances where deans clearly understand the roles that fall within their purview, these responsibilities derive from a broad range of sources and expectations. As such, the situation clearly lends credence to the notion that conflict will arise between the needs and expectations of the administration, faculty, students, and outsiders. Similarly, the sheer weight of responsibilities from so many sources will invariably muddle either the meaning or purpose in attaining the institution's ultimate goals, resulting in ambiguity. In an effort to assess the strength of the relationship between the deans' perceived roles (DTI dimensions) and role conflict and 
ambiguity, we also computed Pearson's product moment correlation coefficients across these constructs.

Finally, a content analysis of the responses to an open-ended question in the survey about future challenges was conducted (Berg, 1998; Manning \& Cullum-Swan, 1994). The responses were pattern-coded by one researcher and verified by a second researcher to provide definitional clarity to the dimensions and a good reliability check (Miles \& Huberman, 1994). Pattern-coding qualitative responses is analogous to the number data-reducing process in factor analysis; the dimensions are derived by the emergence of themes, patterns and/or explanations from the responses to this question (Miles \& Huberman, 1994).

\section{Findings}

\section{Dean Profile}

The overall sample size consisted of 1,370 deans, with a response rate of $60 \%$. The responses received generated a relatively well-balanced sample in terms of gender; $41 \%$ of the responding deans were women. ${ }^{2}$ Roughly $12 \%$ of the respondents held minority status, with African-Americans comprising more than one-half of this segment of the sample.

Deans, on average, were 54 years old. Fewer than $10 \%$ were under the age of 40 years; less than $5 \%$ were 65 years of age or older. The average length of time spent as dean was 5.6 years. Sixteen percent of the respondents had served in their positions for one year or less and only $12.8 \%$ had been deans for more than 10 years. Of the respondents, $58 \%$ worked in public institutions, $42 \%$ in private universities. One-third were deans in research universities; $46 \%$

${ }^{2}$ In previous survey research, where department chairs were randomly sampled, researchers found that less than $10 \%$ of the respondents were female. Assuming that this pattern might hold true for deans as well, colleges of nursing were included in a purposeful attempt to increase the number of female respondents. 
were at comprehensive universities; the remaining $21 \%$ were located at baccalaureate institutions.

\section{Factor Analysis}

The factor matrix for the DTI is presented in Table 1. Thirty-one of the 32 statements from the DTI loaded along six dimensions: external and political relations $(23.5 \%$ of the variance in the data); personal scholarship (8.2\%); leadership (6.1\%), resource management (4.7\%); internal productivity (4.2\%), and academic personnel management (4\%). The variable "develop and evaluate curriculum" did not load on any of the six role dimensions and was subsequently treated as a unique variable.

The variables making up the external/political relations dimension include funding, financial planning, building constituency involvement, promoting diversity, and ensuring alumni support, as well as representing the college to the administration. Those comprising the personal scholarship dimension include maintaining a personal scholarship agenda, keeping current in one's discipline, and demonstrating/modeling scholarship. The leadership dimension involves informing college employees of university and community concerns, soliciting ideas to improve the college, assigning work, and planning/conducting college leadership meetings. The variables that loaded within the dimension of resource management were proper recordkeeping and responsible resource and nonacademic staff management, keeping current with technological change, and compliance with state, federal, and certification agency guidelines. Internal productivity and its role variables included teaching, meeting the goals of the college, and realizing the mission of the university. This dimension also included maintaining a healthy work environment and the encouragement of faculty, chair, and staff professional development

\section{BEST COPY AVAILABLE}


activities. Finally, the dimension of academic personnel management involved the recruiting, selecting, and evaluation of chairs and faculty.

The dimensions of fiscal resource management, internal productivity, and academic personnel management explain very little of the variance in the data, suggesting essential agreement among deans that these are fundamental roles of their positions. Personal scholarship and leadership accounted for a slightly higher percentage of data variability, indicating some disagreement among deans as to the importance of these roles. It is clear that the most controversial part of their work focused upon roles that fell within the realm of external and political relations; almost one-quarter of the data's variance is accounted for by this factor.

\section{DTI/Importance Ranking}

The ranking of the six dimensions by mean scores provides an indication of their importance by the deans in this study (see Table 2 ). Internal productivity ( $\bar{x}=4.37$, on a 5-point scale with $5=$ high, s.d. $=0.43)$, academic personnel management $(\bar{x}=4.27$, s.d. $=0.59)$, and external and political relations $(\bar{x}=4.16$, s.d. $=0.56)$ were the three highest ranked dimensions. The relatively small standard deviations in these three dimensions indicate a fair amount of agreement among the deans as to the primacy of these roles. And, while the mean scores of the remaining three dimensions of leadership $(\bar{x}=3.76$, s.d. $=0.66)$, resource management $(\bar{x}=3.62$, s.d. $=0.68)$, and personal scholarship $(\bar{x}=3.52$, s.d. $=0.87)$ do not reflect the same levels of perceived importance as do the first three, deans do seem to agree on their relative ranking as reflected by standard deviations of less than 1.0 in each case. 


\section{$\underline{\text { RCAQ/Rankings }}$}

Table 3 ranks the 14 items of role conflict and ambiguity found in deans' work. The deans cited as sources of role conflict working with two or more differently operating groups ( $\bar{x}=4.72$, on a 7-point scale with $1=$ not true of my job, $7=$ extremely true of my job), doing things that are accepted by one person and not by others $(\bar{x}=4.38)$, receiving assignments without proper resources/materials to do them $(\bar{x}=4.15)$ or without proper staffing $(\bar{x}=4.14)$. On the measures of role ambiguity, these deans indicated they are quite clear in understanding what their responsibilities are $(\bar{x}=5.51$ on a 7 -point scale, $1=$ not true of my job; $7=$ extremely true of my job), how much authority they have ( $(\bar{x}=4.99)$, knowing what is expected of them $(\bar{x}=4.67)$, and what has to be done $(\bar{x}=4.66)$. In a confirmatory factor analysis, the first six variables in this inventory factored out as the latent construct--role conflict; the remaining six variables loaded on the role ambiguity dimension. Based on previous research, this arrangement was expected (Rizzo et al., 1970).

\section{Relationship between Roles and Role Conflict/Ambiguity}

The relationships between the role dimensions and role conflict and role ambiguity are reported in Table 4. The role dimensions of external/political relations and personal scholarship are correlated with role conflict, positively in the first instance and negatively in the second. As role conflict increases, the importance of the external and political relations dimension appears to increase. This suggests that if role conflict exists, deans may find it easier to concentrate on activities, such as generating support for the college and fundraising. As to the dimension of personal scholarship, it appears that as role conflict increases, the importance of pursuing one's own research and writing will decrease. This perhaps indicates that deans, when forced to choose, really no longer see scholarship as part of the dean's job. A word of caution should be 
issued here, however. While the p-values are significant, they are not highly significant and the correlation coefficients are quite small, which means that the coefficients of determination are minuscule. As a consequence, no causality can be assumed and, in fact, we might conclude that each relationship is a spurious one with little to no meaning. (Role conflict and each of the remaining dimensions do not seem to be directly correlated.)

A more interesting insight can be drawn from the effect that role ambiguity appears to have on all six role dimensions. In each case, the correlation is either moderately or highly significant and negative. The conclusion here is that when role ambiguity is present, deans may have difficulty determining the roles in which they should engage at any one given time. This may prove troublesome. Ill-defined responsibilities, mixed messages as to how much authority deans actually have, unclear or unstated expectations and goals, and a lack of clarity about what 'is to be done and how much time should be spent doing it leave deans in a kind of leadership limbo. In effect, universities may be setting deans up to fail.

\section{Challenges}

Challenges are roles-in-the-making. They do not go away, they simply become routinized. The addition of new or transmuted roles consume deans' time, potentially undermining their effectiveness. When asked to comment on the three greatest challenges they faced in the next 3 to 5 years, seven categories of anticipated challenges emerged. They are shown below with a sampling of the responses for each group:

1. Fiscal: budget and finance, allocation and use of resources, internal and external fundraising.

2. Administration: working with top administration, long-range planning, reorganization, community outreach, public and legislative accountability. 
3. Curriculum and program development: development of curricula and programs, recruiting high quality students, dealing with unprepared students.

4. Faculty: recruit and retain faculty, dealing with difficult personnel, moving faculty toward change.

5. Technology: Distance learning, upgrading technology.

6. Personal balance: Balancing personal and professional lives, attaining personal goals.

7. Diversity: Ensuring diversity of faculty and student population

More than $75 \%$ of the deans agreed that the fiscal, administration, and curriculum and program development challenges were the three most important. Almost $30 \%$ of all respondents to this question rated fiscal challenges number one. Twenty-six percent chose administration as their number one choice; $20 \%$ chose curriculum and program development, about $14 \%$ chose faculty issues; fewer mentioned technology (5\%), personal balance (3\%), or diversity $(<2 \%)$ as top choices. Note: The small number of responses given with respect to diversity appears to indicate that the issue is either superseded in importance by others or that respondents believe that they are able to meet the challenge.

Interestingly, most of the challenges identified parallel the role dimensions that factored in the DTI (see Table 5). The fiscal, administration, technology, and diversity challenges that deans anticipated correspond to the dimensions of external/political relations and resource management. The faculty challenge relates to the dimensions of internal productivity and academic personnel management. The challenge of curriculum and program development relates directly to the unique variable in the DTI; see the comment on page 8 . The personal balance challenge that deans anticipated equates with the personal scholarship dimension. The only role dimension not readily identifiable in the challenges categories is leadership. 


\section{Discussion}

Fundamentally, these responses, when considered from the perspective of role conflict and role ambiguity, indicate that deans are inevitably confronted with situations that require them to engage in roles that conflict and with priorities that remain unfocused. The fact that deans identify challenges they expect to face in the future as parallel to their current roles suggests that the conflict and ambiguity inherent in them will carry forward. That, indeed, deans may perceive that they must be all things to all people. Comments, such as "never have enough time," "frustrated at having others control much of my day," "limited resources and unlimited ambition makes for high stress," and "not for the faint of heart," conjure up images of puppets on strings being pulled in multiple directions. We might raise the following questions. Do deans believe the challenges they face will either expand or be redefined? Don't the demands associated with their current roles and future challenges suggest change? And, if so, doesn't constructive change take leadership? Are deans confident in their ability to lead or are they simply responding as managers to these challenges, and not as leaders?

The deanship as it exists today is enigmatic. Internally, the position sits within a complex web of faculty, students, and administration. Externally, the deanship is the representative conduit through which funding bequests and program requests pass, and where needs, disputes, and demands between faculty and administrators get arbitrated. Moreover, it imposes upon one person the demands of a myriad of jobs, all within the context of serving the institutional good while trying to retain some semblance of normalcy within the individual. Above all else, it should serve as the model of innovation and advancement upon which the reputation of the college depends. Thus, while the dilemma of the deanship manifests itself on the individual who fills the position, the onus of its perpetuation rests, at least in part, with the greater academic 
organization. We raise the question again: Can all this be accomplished without leadership? The resulting paradox faced in higher education administration revolves around whether to fix the dean or the deanship.

Professional development seminars and training in time management may help "fix" the dean. In addition, deans consistently have expressed a need for further training and/or expertise in (a) technical competence in budget/finance and computers/informational systems, (b) dealing with people and communicating with them, and (c) understanding higher education governance issues, such as the administrative environment and legal issues (McBride, 2000; Townsend \& Bassoppo-Moyo, 1996). The truly committed dean might even enroll in an executive MBA program which may provide a viable remedy to the leadership (or at least the management) question. Deans can also learn to maintain balance between their professional and personal lives. Striking a "work-life" balance can lead to more satisfying personal lives and efficiency in work processes (Friedman, Christensen, \& DeGroot, 1998). Clarity in professional and personal purpose, recognition and support of the whole-person (personal and professional) concept, and experimenting with the way work is done are three ways to alleviate the conflict between work and personal priorities (Friedman et al., 1998).

However, we cannot assume that fixing the dean will completely alleviate the problem. The larger issue may rest with colleges and universities. And, for deans to remain effective as leaders and administrators, institutions must respond. First, clear signals must be sent as to institutional priorities. Second, continually expanding the responsibilities of the position only serves to weaken it. Even though the challenges that deans believe they will face in the future fall within today's general role categories, the number of tasks associated with each role continues to proliferate. Colleges and universities must think in terms of redefining the position 
and the organization of work. Ultimately, careful examination of the position could lead to its restructure.

One possible starting point is the concept of shared leadership. Its general premises-shared responsibility, a tangible vision, mutual influence, and a bias for action--seem directed at moving the concept of leadership from a person-centered to a team-based philosophy (Astin, 1996; Astin \& Astin, 1996; Yukl, 1998). Despite agreement in theory, interpretation varies as to the mechanics of implementation. Ostroff (1999), for example, suggests a cluster of empowered leaders and followers engaging in cross-functional purposes. Elsewhere, there is reference to the coordinated efforts of "post-heroic leadership" which makes everyone in the group a leader, responsible at all levels, and collaborative in their management of the group (Bradford \& Cohen, 1998; Yukl, 1998). There are also "teams at the top," which can "vary their composition, behavior pattern, and leadership approach to optimize and better integrate individual, team, and nonteam performance (Katzenbach, 1998). Katzenbach (1998) advocates for a leadership team, which comprises "a small number of people with complementary skills who are committed to common purposes, performance goals, and leadership approaches for which they hold themselves mutually accountable" (p. 217). In the end, however, the three models described preserve the sole leader at the top of the organization. Katzenbach recognizes this dilemma and comments, "We create a contradiction for those in the 'leadership' role: the expectation that work would be better served by a team approach runs up against [traditional] expectations of the position. As a result, in most organizations, leadership at the top rarely functions as a team. Team performance at the top is all about doing work together, about collective action. [In such situations] real work [goes beyond] open discussion, debate, decision making, and delegation of authority" (1998, p. 111). 
Rarely does rethinking positions of authority and organizational structure take place in traditional institutions, such as universities. But, such a move might prove fruitful. Deans oversee professional organizations (colleges) that are in some ways similar to large professional partnerships or organizations in the private sector (e.g., attorneys, accountants). And these partnerships operate within the greater enterprise (or partnership) we call the university. Often the responsibilities exceed the management and leadership capacity of one person. Fifteen years ago, Austin (1984) suggested that universities look at innovative arrangements of work loads. Bensimon and Neumann (1993) proposed such a variant of shared leadership in their examination of the concept of complex, team-centered leadership in colleges and universities. They asserted that teams dominated by solo leaders are limited in their abilities to effect and respond to change. In proffering the concept of the complex team, they advocated a "more open and equalized ... conception of leadership ... as a shared process and a shared responsibility... . More effective at discerning complexity in their environments, the complex team demands shared responsibility for thinking as much as it requires shared responsibility for doing" (p.145). Once in place, the leadership team shares all responsibilities (Bensimon and Neumann, 1993). Team leadership, in its purest sense although rare, is by no means a new concept in business. In 1991, Nordstrom, Inc., created a co-presidency that comprised four non-family members. This effort at shared leadership was instigated in an effort to pull the national retailer out of a slump. These co-presidents described their functions as concentrating "on a different part of the business, but on company matters [they] speak with one voice" (Schwadel, 1991). Although this co-CEOship has undergone several executive shifts--adding Nordstrom family member CEOs to share the position, removing all family members down to two, returning to one CEO and, most recently in September, 2000, removing the sole CEO and reinstating a four- 
family-member co-CEO position (Spurgeon, 2000)--Nordstrom, Inc., shows no hesitation at the thought of sharing the leadership responsibilities for the good of the company.

Likewise, Charles Schwab Corp., an investment brokerage firm, now employs co-CEOs to separately handle the responsibilities of president (David Pottruck) and chairman (Charles Schwab) (McGeehan, 1997). The investment banking business of Goldman, Sachs \& Co. has a history of using co-leaders to run their corporation amid a collegial culture. Those who have succeeded in Goldman, Sachs \& Co., Stephen Friedman and Robert Rubin, for instance, stress the importance of "compatible chemistry," and conducting the sharing aspect of the title as "giving of one's self and ideas to the other while being responsive of [the other's] needs" (Lublin \& Schellhardt, 1998, p. C14).

In 1997, Centigram Corporation, a communication technology company, created an interim co-CEOship while it sought a permanent CEO. The two-person team comprised the general manager/executive vice-president (whose strengths were in sales and marketing) and the CFO (whose strength lay in operations). These two individuals jointly exercised their respective expertise in the day-to-day executive functions. Benefits of this arrangement were that responsibilities were divided and assumed according to strengths, making for efficient operations and a decreased sense of being overwhelmed in the job. Disadvantages were that the necessity for constant communication often slowed the decision-making process and departments often made end-runs around the "two-headed dragon" of leadership. The conjoint nature of this arrangement, however, is summed up by Dennis Barsema, one of the co-CEOs:

It [is] very important that the co-CEOs not become disjointed and not let people get in between them. ... In order for any "co-" relationship to work, both people have to have egos that don't need to be number 1 . If ego becomes a factor, one will try to destroy the other person, or at least make them look bad in some way (Barsema, 2000). 
Even educators are beginning to test the waters. In 1999, the graduate school of education at Harvard revealed its approach to the innovation of a co-deanship: two administrators share the position, an office with two desks and two computers, and a joint space for meetings. They share the work and the salary stipend, and continue to work jointly on research ("Peer Review," 1999, p. A14).

\section{Conclusion}

As the roles of academic deans continue to expand, challenges that arise from them will become routine. As a consequence, deans will have less time, and less time coupled with more to do usually impacts the manner in which they do their jobs. At present, it appears that although their roles will probably increase and perhaps conflict with each other, deans will be able to deal with any such conflict. However, if roles continue to remain ill-defined and university priorities continue to be vague, deans may not be able to meet these priorities and could be less effective as administrators than they have been in the past. Any solutions generated will more than likely need to stretch the bounds of institutional imagination; for too long, deans have existed within the context of a tension-ridden climate. They cannot be left to flounder in this environment if we are to preserve the quality of the institution and the persons who run it.

The variants on shared leadership, both in education and business, are not without problems. "The co-CEO role is tough to make work" (Lublin \& Schellhardt, 1998, p. C14); and, given the way some of the companies cited herein have responded, it seems to be an as-yet perfected possibility and one that must be judiciously applied. It is not, however, an impossibility, but, perhaps, just what is needed to fix the deanship. 


\section{REFERENCES}

Anonymous. (November 26, 1999). Peer review. Chronicle of Higher Education, A14.

Astin, H. (1996). Leadership for social change. About Campus(July-August), 4-10.

Astin, H. S., \& Astin, A. W. (1996). A social change model of leadership development guidebook. Version III. Los Angeles: UCLA Higher Education Research Institute.

Austin, A. E. (1984). The work experience of university and college administrators. American Association of University Administrators--ERIC Clearinghouse on Higher Education, 6(1), 1-6.

Barsema, D. (October 17, 2000). Personal email communication.

Bensimon, E. M., \& Neumann, A. (1993). Redesigning collegiate leadership: Teams and teamwork in higher education. Baltimore: The Johns Hopkins University Press.

Berg, B. L. (1998). Qualitative research methods for the social sciences ( $3 \mathrm{~d}$ ed.). Boston: Allyn and Bacon.

Biddle, B. J. (1979). Role theory: Expectations, identities, and behaviors. New York: Academic Press.

Bradford, D. L., \& Cohen, A. R. (1998). Power up: Transforming organizations through shared leadership. New York: John Wiley \& Sons, Inc.

Cohen, A. R. (1959). Situational structure, self esteem, and threat-oriented reactions to power. In D. Cartwright (Ed.), Studies in Social Power (pp. 35-52). Ann Arbor, MI: Institute for Social Research, University of Michigan.

Dibden, A. J. (Ed.). (1968). The academic deanship in American colleges and universities. Carbondale, IL: Southern Illinois University Press.

Dill, W. R. (1980). The deanship: An unstable craft. In D. E. Griffiths \& D. J. McCarty (Eds.), The dilemma of the deanship (pp. 261-284). Danville, IL: The Interstate Printers \& Publishers, Inc.

Fagin, C. M. (1997). The leadership role of a dean. In M. J. Austin \& F. L. Ahearn \& R. A. English (Eds.), The professional dean: Meeting the leadership challenges (Summer ed., Vol. 25). San Francisco, CA: Jossey-Bass Publishers.

Friedman, S. D., Christensen, P., \& DeGroot, J. (1998). Work and life: The end of the zero-sum game. Harvard Business Review(November-December), 119-129. 
Gardner, W. E. (1992). Once a dean: Some reflections. Journal of Teacher Education, 43(5), 357-366.

Gates, G. S. (2000). Teaching-related stress: The emotional management of faculty. Review of Higher Education, 23(4), 469-490.

Gmelch, W. H., \& Miskin, V. D. (1993). Strategic leadership skills for department chairs. Boston, MA: Anker.

Gmelch, W. H., Wolverton, M., Wolverton, M. L., \& Hermanson, M. (1996). The 1996 national survey of academic deans in higher education. Pullman, WA: Washington State University, The Center for Academic Leadership.

Gross, N., Mason, W., \& McEachern, A. (1958). Explorations in role analysis: Studies of the school superintendent role. New York: John Wiley \& Sons.

Hair, J. F., Anderson, R. E., Tatham, R. L., \& Black, W. C. (1992). Multivariate data analysis with readings ( $3 \mathrm{~d}$ ed.). New York: Macmillan Publishing Co.

Kahn, R. L., Wolfe, D. M., Quinn, R. P., \& Snoek, J. D. (1964). Organizational stress: Studies in role conflict and ambiguity. New York: John Wiley \& Sons, Inc.

Katzenbach, J. R. (1998). Teams at the top: Unleashing the potential of both teams and individual leaders. Boston: Harvard Business School Press.

Lublin, J. S., \& Schellhardt, T. D. (April 7, 1998). The big umbrella: Travelers/Citicorp merger-history shows sharing of power can lead to clashes, breakups. Wall Street Journal, pp. C14.

Mandell, M. M. (1956). Supervisory characteristics and ratings: A summary of recent research. Personnel, 32, 435-440.

Manning, P. K., \& Cullum-Swan, B. (1994). Narrative, content and semiotic analysis. In N. K. Denzin \& Y. S. Lincoln (Eds.), Handbook of qualitative research. Thousand Oaks, CA: SAGE Publications, Inc.

McBride, S. A. (2000). Academic economics: The academic dean and financial management, New Directions for Community Colleges (pp. 51-62). San Francisco: Jossey-Bass Publishers, Inc.

McGeehan, P. (December 2, 1997). Charles Schwab's Pottruck will share title of CEO with company's founder. Wall Street Journal, pp. B5.

Miles, M. B., \& Huberman, A. M. (1984). Qualitative data analysis. Beverly Hills, CA: SAGE Publications, Inc. 
Norusis, M. J. (1994). SPSS professional statistics 6.1. Chicago, IL: SPSS, Inc.

Ostroff, F. (1999). The horizontal organization: What the organization of the future looks like and how it delivers value to customers. New York: Oxford University Press.

Parsons, T. (1951). The social system. Glencoe, IL: Free Press.

Rizzo, J. R., House, R. J., \& Lirtzman, S. I. (1970). Role conflict and ambiguity in complex organizations. Administrative Science Quarterly, 15, 150-163.

Sarros, J. C., Gmelch, W. H., \& Tanewski, G. A. (1998). The academic dean: A position in need of a compass and clock. Higher Education Research \& Development, 17(1), 65-88.

Scott, R.A. (1979). The "amateur dean" in a complex university: An essay on role ambiguity. Liberal Education, 65(4), 445-452.

Schwadel, F. (May 21, 1991). Nordstrom taps 4 non-family members for newly created post of co-president. Wall Street Journal, pp. C9.

Spurgeon, D. (September 8, 2000). In return to power, the Nordstrom family finds a pile of problems--A father and son must chart new course after a fling with halters and hip-hop. Wall Street Journal, pp. B1.

Townsend, B. K., \& Bassoppo-Moyo, S. (1996). If I'd only known: Administrative preparation that could have made a difference. Paper presented at the Annual Meeting of the American Educational Research Association, New York, NY.

Wispe, L. G., \& Thayer, P. G. (1957). Role ambiguity and anxiety in an occupational group. Journal of Social Psychology, 46, 41-48.

Wolverton, M., Gmelch, W. H., Wolverton, M. L., \& Sarros, J. C. (1999). Stress in academic leadership: U.S. and Australian department chairs/heads. The Review of Higher Education, 22(2), 165-185.

Wolverton, M., Wolverton, M. L., \& Gmelch, W. H. (1999). The impact of role conflict and ambiguity on academic deans. Journal of Higher Education, 70(1), 80-106.

Yukl, G. (1998). Leadership in organizations ( 4th ed.). Upper Saddle River, NJ: Prentice-Hall, Inc. 
Table 1. Principal Components Analysis--Deans' Task Inventory (DTI)

\begin{tabular}{|c|c|c|c|c|c|c|}
\hline \multirow[b]{2}{*}{ Variable } & \multicolumn{6}{|c|}{ Varimax Rotated Factor Loadings } \\
\hline & $\mathrm{Fl}$ & F2 & F3 & F4 & F5 & F6 \\
\hline \multicolumn{7}{|l|}{ External and Political Relations } \\
\hline Build relationships with external community/stakeholders & .73 & .16 & .22 & .03 & .05 & -.10 \\
\hline Obtain and manage external funds (grants, contracts, donations) & .68 & .02 & .15 & .21 & -.08 & .07 \\
\hline Foster alumni relations & .67 & .13 & .25 & .02 & .08 & -.09 \\
\hline Develop and initiate long-range college goals & .49 & .06 & .33 & -.13 & .07 & .21 \\
\hline Financial planning, budget preparation and decision-making & .46 & .01 & .02 & .40 & .22 & .28 \\
\hline Foster gender and ethnic diversity in the college & .46 & .10 & .01 & .23 & .23 & .20 \\
\hline Represent the college to the administration & .41 & -.08 & .11 & .02 & .21 & .28 \\
\hline Cronbach's alpha & .75 & . & & $\ldots$ & & \\
\hline \multicolumn{7}{|l|}{ Personal Scholarship } \\
\hline Maintain own scholarship program \& associated professional activities & .07 & .88 & .09 & .11 & .04 & .05 \\
\hline Remain current with my own academic discipline & -.01 & .81 & .11 & .15 & .12 & .03 \\
\hline $\begin{array}{l}\text { Demonstrate scholarship and model scholarship by publishing and/or } \\
\text { presenting papers regularly }\end{array}$ & .18 & .77 & .06 & .05 & .02 & .03 \\
\hline Maintain and foster my own professional growth & .04 & .70 & .06 & .17 & .33 & -.01 \\
\hline Cronbach's alpha & & .84 & & & & \\
\hline
\end{tabular}

\section{Leadership}

Solicit ideas to improve the college

Inform college employees of university and community concerns

$\begin{array}{llllll}.27 & .15 & .64 & .07 & .13 & .13\end{array}$

$\begin{array}{llllll}.07 & -.04 & .63 & -.02 & .06 & .08\end{array}$

Plan and conduct college leadership team meetings

Assign duties to chairs and directors

$\begin{array}{llllll}.32 & .11 & .63 & -.02 & .06 & .08\end{array}$

Coordinate college activities with constituents

Represent college at professional meetings

$\begin{array}{llllll}.04 & .087 & .61 & .27 & -.07 & .38\end{array}$

$\begin{array}{llllll}.26 & .11 & .52 & .21 & .12 & -.01\end{array}$

Cronbach's alpha

$\begin{array}{llllll}.32 & .28 & .40 & .13 & .27 & -.12\end{array}$

\section{.76}

\section{Resource Management}

Manage non-academic staff

Assure the maintenance of accurate college records

Manage college resources (grants, facilities and equipment)

Keep current with technological changes

Comply with state, federal and certification agency guidelines

$\begin{array}{rrrrrr}.03 & .16 & .20 & .66 & .02 & -.02 \\ .01 & .18 & .13 & .65 & .23 & -.06 \\ .44 & -.03 & -.06 & .60 & -.01 & .22 \\ .17 & .25 & .18 & .44 & .17 & -.04 \\ .18 & .21 & .32 & .33 & .25 & -.02\end{array}$

Cronbach's alpha 


\section{Internal Productivity}

Maintain effective communication across departments/divisions

Foster good teaching

Communicate goals/mission to college employees/constituents

Maintain conducive work climate (i.e., manage conflict situations)

Encourage faculty, chair and staff professional development activities

Participate in college and university committee work

$\begin{array}{rrrrrr}.14 & .09 & .12 & .05 & .72 & .04 \\ -.06 & .14 & .01 & .13 & .59 & .13 \\ .46 & -.02 & .24 & .07 & .51 & -.02 \\ .06 & .07 & .11 & .11 & .46 & .36 \\ .17 & .22 & .16 & .06 & .42 & .25 \\ -.13 & .19 & .34 & .33 & .41 & -.12\end{array}$

Cronbach's alpha

.65

\section{Personnel}

Recruit and select chairs and faculty

Evaluate chair and faculty performance

Supervise department chairs and directors

$\begin{array}{llllll}.07 & .01 & -.02 & -.07 & .04 & .71\end{array}$

$\begin{array}{llllll}.03 & .06 & .11 & .02 & .19 & .68\end{array}$

$\begin{array}{llllll}-.08 & -.03 & .32 & .38 & .02 & .46\end{array}$

Cronbach's alpha

Eigenvalue

Percentage of variance accounted for

$\begin{array}{llllll}7.4 & 2.7 & 2.0 & 1.5 & 1.3 & 1.2\end{array}$

Cumulative percentage of variance accounted for

$\begin{array}{llllll}23.0 & 8.3 & 6.1 & 4.6 & 4.0 & 3.9\end{array}$

49.9 
Table 2. Role Dimension Rankings

\begin{tabular}{|c|c|c|c|c|}
\hline Dimension & Mean & s.d. & Min & $\operatorname{Max}$ \\
\hline Internal productivity & 4.37 & 0.43 & 3.00 & 5.00 \\
\hline Academic personnel management & 4.27 & 0.59 & 1.00 & 5.00 \\
\hline External \& political relations & 4.16 & 0.56 & 2.29 & 5.00 \\
\hline Leadership & 3.76 & 0.66 & 1.33 & 5.00 \\
\hline Resource management & 3.62 & 0.68 & 1.60 & 5.00 \\
\hline Personal scholarship & 3.52 & 0.87 & 1.00 & 5.00 \\
\hline
\end{tabular}


Table 3. Role Conflict \& Ambiguity Responses

\begin{tabular}{llll}
\hline Variable & Mean & s.d. \\
\hline
\end{tabular}

\section{Role Conflict}

I work with two or more groups who operate quite differently

I do things that are apt to be accepted by one person and

not accepted by others

I receive an assignment without the proper resources and materials to execute it

I receive an assignment without the proper staffing to complete it

I have to do things that should be done differently

I have to work on unnecessary things

I receive incompatible requests from two or more people

\section{Role Ambiguity**}

I know what my responsibilities are

I feel certain about how much authority I have

I know exactly what is expected of me

Explanation is clear regarding what has to be done

Clear planned goals exist for my job

*1=low, $7=$ high

**These items were reverse-scored for analysis. 
Table 4. Correlations of Roles, Conflict and Ambiguity

\begin{tabular}{|c|c|c|c|c|c|c|}
\hline & $\begin{array}{l}\text { External/ } \\
\text { Political }\end{array}$ & $\begin{array}{l}\text { Personal } \\
\text { Scholarship }\end{array}$ & Leadership & $\begin{array}{l}\text { Resource } \\
\text { Mgmt }\end{array}$ & $\begin{array}{l}\text { Intermal } \\
\text { Productivity }\end{array}$ & $\begin{array}{l}\text { Academic } \\
\text { Personnel } \\
\text { Mgmt }\end{array}$ \\
\hline Role conflict & $\begin{array}{r}0.095 \\
\mathrm{p}=0.015\end{array}$ & $\begin{array}{r}-0.096 \\
p=0.013\end{array}$ & $\begin{array}{r}-0.001 \\
p=0.976\end{array}$ & $\begin{array}{r}-0.010 \\
p-0.804\end{array}$ & $\begin{array}{r}-0.050 \\
p=0.201\end{array}$ & $\begin{array}{r}0.014 \\
p=0.713\end{array}$ \\
\hline $\begin{array}{l}\text { Role } \\
\text { ambiguity }\end{array}$ & $\begin{array}{r}-0.166 \\
p=0.000\end{array}$ & $\begin{array}{r}-0.081 \\
p=0.038\end{array}$ & $\begin{array}{r}-0.171 \\
p=0.000\end{array}$ & $\begin{array}{r}-0.080 \\
p=0.039\end{array}$ & $\begin{array}{r}-0.102 \\
p=0.008\end{array}$ & $\begin{array}{r}-0.112 \\
p=0.004\end{array}$ \\
\hline
\end{tabular}


Table 5. A Comparison of Current Roles and Future Challenges

\begin{tabular}{|c|c|}
\hline Role Dimension & Future Challenges \\
\hline $\begin{array}{l}\text { ExternaVpolitical relations } \\
\text { Funding } \\
\text { Financial planning } \\
\text { Build constituency involvement } \\
\text { Promote diversity } \\
\text { Ensure alumni support } \\
\text { Represent college to administration } \\
\text { Resource Management } \\
\text { Proper recordkeeping } \\
\text { Resource \& nonacademic staff management } \\
\text { Compliance with state, federal \& } \\
\text { certification agency guidelines } \\
\text { Keep current with technological change }\end{array}$ & $\begin{array}{l}\text { Fiscal } \\
\text { Budget and finance } \\
\text { Allocation and use of resources } \\
\text { Internal and external fundraising } \\
\\
\text { Administration } \\
\text { Work with top administration } \\
\text { Long-range planning } \\
\text { Reorganization } \\
\text { Community outreach } \\
\text { Public/legislative accountability } \\
\text { Technology } \\
\text { Distance learning } \\
\text { Upgrade technology } \\
\text { Diversity } \\
\text { Ensure diversity of faculty and students }\end{array}$ \\
\hline $\begin{array}{l}\text { Internal Productivity } \\
\text { Teaching } \\
\text { Meet goals of the college } \\
\text { Realize mission of the university } \\
\text { Maintain healthy work environment } \\
\text { Encourage faculty, chair \& staff } \\
\text { professional development activities } \\
\text { Academic Personnel Management } \\
\text { Recruit, select, and evaluate chairs } \\
\text { Recruit, select, and evaluate faculty }\end{array}$ & $\begin{array}{l}\text { Faculty } \\
\text { Recruit and retain faculty } \\
\text { Deal with difficult personnel } \\
\text { Move faculty toward change }\end{array}$ \\
\hline $\begin{array}{l}\text { Personal Scholarship } \\
\text { Maintain personal scholarship agenda } \\
\text { Keep current in own discipline } \\
\text { Demonstrate/model scholarship }\end{array}$ & $\begin{array}{l}\text { Personal Balance } \\
\text { Balance personal and professional lives } \\
\text { Attain personal goals }\end{array}$ \\
\hline NO PARALLEL DIMENSION & $\begin{array}{l}\text { Curriculum and Program Development } \\
\text { Development of curricula and programs } \\
\text { Recruit high-quality students } \\
\text { Deal with unprepared students }\end{array}$ \\
\hline $\begin{array}{l}\text { Leadershtp } \\
\text { Inform employees of univ/comm concerns } \\
\text { Solicit ideas to improve the college } \\
\text { Assign work } \\
\text { Plan/conduct college leadership meetings }\end{array}$ & NO PARALLEL CHALLENGE \\
\hline
\end{tabular}




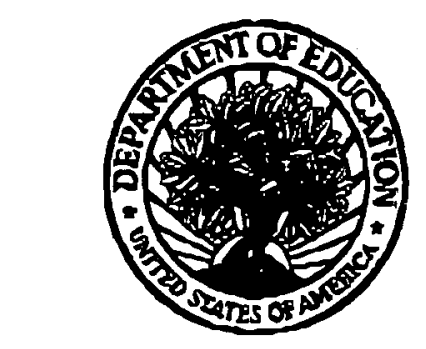

\section{U.S. Department of Education
Office of Educational Research and improvement (OERI)
National Lbrary of Education (NLG) Educational Resources information Centor (ERIC) REPRODUCTION RELEASE}

I. DOCUMENT IDENTIFICATION:

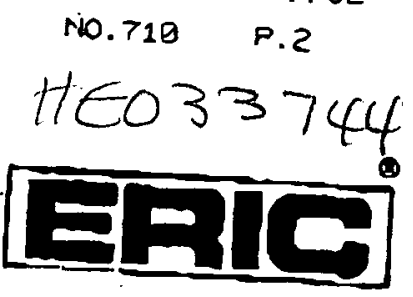

Tille: THE ROUB + CHALUENGEZ OF DEANIS

Author(s): MIMI WOLVERTM, JONI MONTEZ, WALT GMUECA
Corporate Source:

Publication Date:

\section{REPRODUCTION RELEASE:}

In order to dissemingte as whaly as pot

monthy abstrae journal of the ERC as system, Rasourcas in Ecoucalion (RIE)

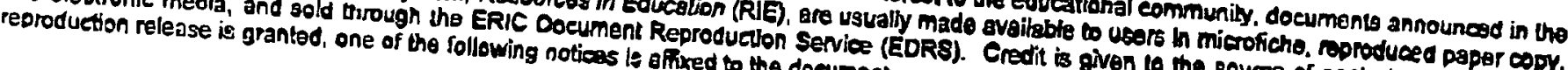

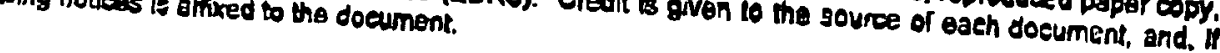
of the page.

The agmple slleter ohrwn belaw wip bo

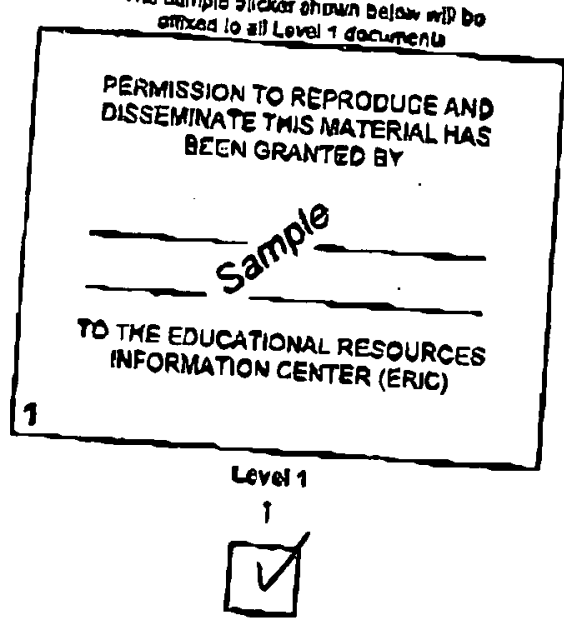

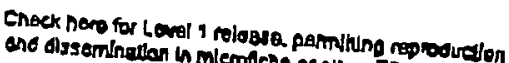

modie lag. Alocronid ond ogper copl.

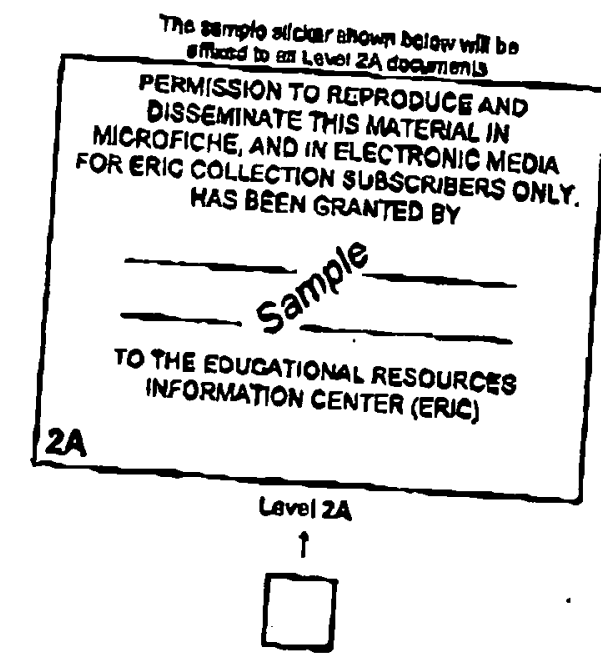

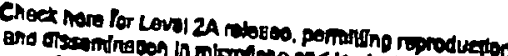

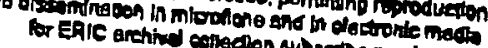

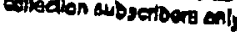

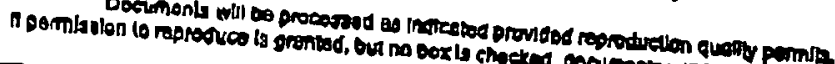

of the following threo options and slen at the oottom

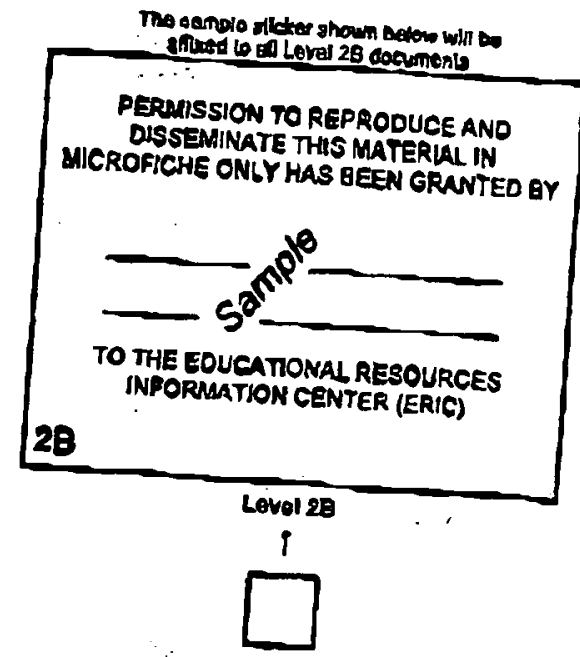

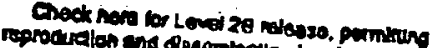

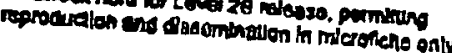

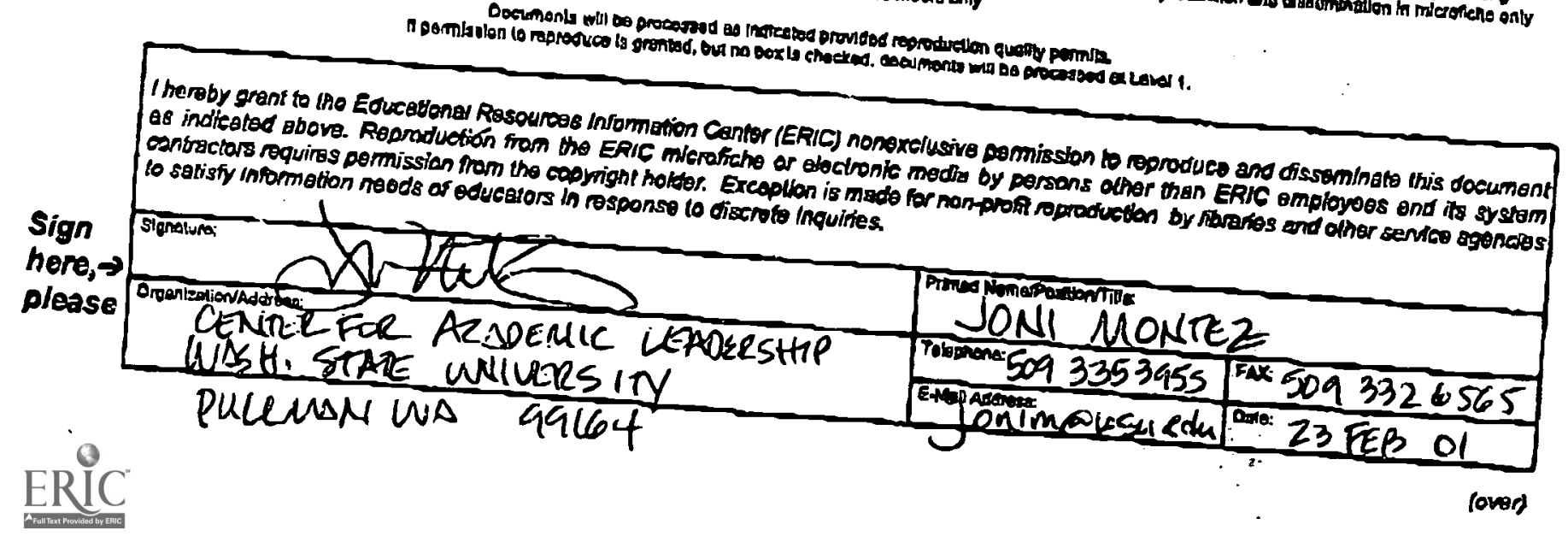

